Науковий вісник НЛтУ України
Scientific Bulletin of UNFU
https://nv.nltu.edu.ua
$\begin{gathered}\text { https://doi.org/10.36930/40300119 } \\ \text { Article received 17.02.2020 p. } \\ \text { Article accepted 27.02.2020 p. } \\ \text { UDK 336.717.8 }\end{gathered}$

Н. П. Дребот, Я. А. Танчак, М. М. Миколишин

Львівський навчально-науковий інститут ДВНЗ "Університету банківської справи", м. Львів, Україна

\title{
ТЕНДЕНЦІЇ РОЗВИТКУ НЕБАНКІВСЬКИХ ФІНАНСОВИХ УСТАНОВ НА РИНКУ ФІНАНСОВИХ ПОСЛУГ УКРАЇНИ
}

\begin{abstract}
У сучасних умовах розвитку економіки ступінь розвитку фінансового ринку характеризується великою кількістю та різноманітністю фінансових посередників та асортиментом фінансових послуг, які вони надають учасникам ринку. Небанківські фінансові установи $є$ професійними учасниками ринку фінансових послуг, які забезпечують спільне інвестування, управління активами, посередництво у купівлі-продажу фінансових інструментів, гарантійні операції тощо. Сучасні тенденції розвитку фінансових систем розвинених країн світу свідчать про дедалі вагомішу роль у мобілізації фінансових ресурсів саме фінансових посередників, типи і види яких визначаються рівнем розвитку фінансових відносин. Важливе місце серед фінансових посередників належить небанківським фінансовим установам, кожен вид яких відіграє свою роль, має свої функції та призначення. Наявне розмаїття небанківських фінансових установ в Україні вимагає застосування, 3 одного боку, специфічних підходів до їх державного регулювання, з іншого, універсальних заходів відродження і розвитку ринку фінансових послуг. Вирішення зазначеної проблеми передбачає аналіз та тенденції розвитку небанківських фінансових установ, який стане основою побудови системи порівняних показників оцінки ефективності їх діяльності, результати якої стануть інформаційною базою для прийняття ефективних рішень з метою реалізації стратегії реформування державного регулювання ринків небанківських фінансових послуг та забезпечення ефективного управління ними на рівні держави. У роботі оцінено діяльність основних небанківських фінансово-кредитних установ. Проаналізовано основні показники діяльності небанківських фінансових установ у розрізі основних сегментів сучасного ринку фінансових послуг. Визначено проблеми, які гальмують розвиток ринку страхових послуг, ринку недержавного пенсійного забезпечення та ринку ломбардного кредитування. Зроблено висновок про потребу негайного вирішення системних проблем на ринку фінансових послуг для забезпечення його ефективного та стабільного функціонування в майбутньому.
\end{abstract}

Ключові слова: Нацкомфінпослуг; фінансові компанії; ломбарди; кредитні спілки; пенсійні фонди; страхові компанії.

Вступ. Розвиток фінансового ринку, підприємництва та конкурентного середовища в Україні зумовлюе перебудову усіх складових інвестиційного середовища. Важливого значення при цьому набуває діяльність небанківських фінансових установ, які задовольняють потреби учасників фінансового ринку через надання їм максимально широкого асортименту вузькоспеціалізованих фінансових послуг. Особливістю сучасного етапу розвитку небанківських фінансових установ є потреба у поліпшенні не тільки кількісних, а і якісних показників ї діяльності на фінансовому ринку. Підвищення ефективності системи функціонування небанківського фінансового посередництва стає найважливішим чинником, що здатний забезпечити розвиток вітчизняного фінансового ринку.

Ринок небанківських фінансових послуг істотно впливає на функціонування різних сфер економіки держави, iii інвестиційну привабливість, входження України до європейського фінансового простору, життєвий рівень громадян, збереження та відтворення їх заощаджень. Саме тому стан ринків небанківських фінансових послуг, перспективи розвитку, проблеми, що виникають у процесі їх діяльності, i шляхи подолання цих проблем повинні бути предметом постійного аналізу та відповідного реагування органів державної влади.

Об'єктом дослідження є небанківські фінансові установи в Україні.

Предметом дослідження є сукупність теоретичних, методологічних та практичних аспектів діяльності небанківських фінансових установ на фінансовому ринку України.

Метою дослідження є встановлення місця та значення кожної небанківської установи на фінансовому ринку України.

Завданням дослідження є аналіз діяльності небанківських фінансових установ в Україні, визначення факторів впливу на їх розвиток.

Наукова новизна дослідження та практична значу-

Інформація про авторів:

Дребот Наталія Петрівна, канд. екон. наук, доцент, кафедра фінансів, банківської справи і страхування. Email: drebot72@gmail.com; https://orcid.org/0000-0003-0742-0967.

Танчак Ярина Андріївна, канд. екон. наук, доцент, кафедра фінансів, банківської справи і страхування. Email: jarunatanchak@ukr.net; https://orcid.org/0000-0003-1787-4516

Миколишин Марта Михайлівна, канд. екон. наук, викладач, кафедра фінансів, банківської справи і страхування. Email: marta_1986@ukr.net; https://orcid.org/0000-0002-6605-8964

Цитування за ДСТУ: Дребот Н. П., Танчак Я. А., Миколишин М. М. Тенденції розвитку небанківських фінансових установ на ринку фінансових послуг України. Науковий вісник НЛтУ України. 2020, т. 30, № 1. С. 109-114.

Citation APA: Drebot, N. P., Tanhak, Ya. A., \& Mykolyshyn, M. M. (2020). Trends in the development of non-banking financial institutions in the financial services market of Ukraine. Scientific Bulletin of UNFU, 30(1), 109-114. https://doi.org/10.36930/40300119 
щъість отриманих результатів. Отримані в процесі дослідження обраної проблематики наукові результати вирішують актуальну проблему розроблення й обгрунтування теоретичних і методичних підходів, а також формування концептуального та аналітичного забезпечення розвитку небанківських фінансових установ. Зокрема, теоретично обгрунтовано сучасний стан розвитку небанківських фінансових установ та комплекс аналітичних і методичних підходів до забезпечення функціонування їх інституційної структури. Систематизовано та визначено проблеми щодо тенденцій розвитку небанківських фінансових установ, що дає змогу встановити ступінь впливу кожної фінансової установи на стан національної економіки та визначити стратегічні напрями подальшого їх розвитку.

Матеріал і методи дослідження. Теоретико-методологічною основою дослідження є фундаментальні засади економічної теорії, теорії фінансів, державного регулювання економіки у сфері організації діяльності небанківських фінансових установ. Для вирішення поставлених завдань використано такі методи пізнання економічних явищ та процесів: теоретичного узагальнення, синтезу, індукції та дедукції - для обгрунтування сутності та діяльності небанківських установ на ринку фінансових послуг України; структурно-логічного аналізу - для формування цілісного підходу в проведених дослідженнях; порівняння - для виділення особливостей розвитку небанківських фінансових установ; статистичний метод - для оброблення інформації, що характеризує ринок небанківських фінансових послуг України на загальнодержавному рівні.

Інформаційною базою дослідження є законодавчі та нормативно-правові акти, що регламентують функціонування небанківських фінансових інститутів України, офіційні матеріали Державної служби статистики України, НБУ, Міністерства фінансів України, НКЦПФР, Нацкомфінпослуг, статті науковців та економістівпрактиків.

Аналіз літературних джерел. Проблеми становлення і розвитку небанківських фінансових інститутів досліджують такі вітчизняні науковці, як: М. О. Коніна, I. І. Чуницька, С. М. Ксьондз, О. Л. Лаврик, А. О. Харламова, І. О. Школьник, В. М. Кремень, О. Л. Руда, Є. А. Поліщук, Л. В. Діденко, Є. С. Осадчий, О. В. Клименко, Ж. В. Прокопенко та інші [3, 6, 9, 11, 12].

Зокрема, М. О. Коніна зосереджує увагу на тому, що для України становлення та подальший розвиток фінансового ринку є передумовою появи потужного джерела інвестицій, що будуть спрямовуватися в сектори економіки держави, шляхом акумуляції вільних грошових коштів [4].

Табл. 1. Динаміка основних показників діяльності кредитних спілок, станом на

\begin{tabular}{|c|c|c|c|c|c|c|}
\hline Показник & 2014 & 2015 & 2016 & 2017 & 2018 & $2019 *$ \\
\hline Кількість зареєстрованих кредитних спілок & 589 & 588 & 462 & 378 & 358 & 352 \\
\hline Кількість членів КС, тис. осіб & 821,60 & 764,60 & 642,90 & 564,10 & 479,00 & 467,00 \\
\hline Загальні активи, млн грн & 2338,70 & 2064,30 & 2032,50 & 2169,80 & 2218,40 & 2368,90 \\
\hline Капітал, млн грн & 1048,70 & 1040,90 & 1044,40 & 1062,50 & 977,10 & 1080,30 \\
\hline Кредити, надані членам КС, млн грн & 1994,40 & 1792,70 & 1799,50 & 1902,30 & 2018,00 & 2187,50 \\
\hline Внески членів КС на депозитні рахунки, млн грн & 989,80 & 855,20 & 831,80 & 937,00 & 1045,70 & 1094,40 \\
\hline
\end{tabular}

Чуницька I. I. у своїх працях досліджує оптимальність розподілу і перерозподілу фінансових ресурсів через фінансовий ринок шляхом забезпечення переливання фінансових ресурсів у ті галузі економіки, які їх потребують, запобігаючи формуванню дефіциту [2].

Ксьондз С. М. наголошує на значущості фінансового посередництва на ринку фінансових послуг України через сприяння зменшенню вартості фінансових операцій, підвищенні ліквідності фінансових активів, диверсифікації ризику, створенні умов для активізації роботи всіх учасників ринку фінансових послуг [5].

Однак, незважаючи на значний обсяг публікацій із досліджуваної тематики, узагальнення й аналіз опублікованих робіт дали підстави зробити висновок про те, що проблеми пошуку оптимальних механізмів, спрямованих на забезпечення комплексного розвитку небанківських фінансових установ в Україні, залишаються досі недостатньо розробленими як у науковому, так і в організаційно-прикладних аспектах.

Результати дослідження та їх обговорення. Відповідно до Закону України "Про фінансові послуги та державне регулювання ринків фінансових послуг" ринок фінансових послуг - це сфера діяльності учасників ринку фінансових послуг для надання та споживання певних фінансових послуг [1]. Державне регулювання небанківського фінансового сектору на ринку фінансових послуг належить до компетенції Національної комісії, що здійснює державне регулювання у сфері ринків фінансових послуг (Нацкомфінпослуг).

На сьогодні небанківські фінансові установи України представляють фінансові компанії, ломбарди, кредитні спілки, пенсійні фонди, страхові компанії, інвестиційні фонди, довірчі товариства і деякі інші установи.

На кінець 2018 р. кількість небанківських фінансових установ становила 2 024, 3 них: 940 фінансових компаній (займають найбільшу частку - 46,4%), 359 ломбардів, 358 кредитних спілок, 281 страхова компанія, 62 недержавні пенсійні фонди, 22 адміністратори недернансові компанії та страхові компанії володіють основною частиною активів, відповідно 63,45 та 32,15\%. Водночас, сукупні активи ломбардів, недержавних пенсійних фондів та кредитних спілок становлять лише 4,4 \% від активів небанківського фінансового сектору [7].

Обсяги активів кредитних спілок, як свідчать дані табл. 1, є незначними, їх роль у формуванні фінансового забезпечення розвитку економіки не $\epsilon$ провідною. Зважаючи на те, що основною функцією кредитних спілок є взаємокредитування громадян, то природно, що частка їх активів, порівняно з іншими фінансовими усжавних пенсійних фондів та 2 довірчих товариства. Фітановами, буде невеликою [8]

$$
\text { *Примітка: дані за } 6 \text { місяців. }
$$

За результатами аналізу поданої інформації, відзначаємо, що на кінець 2018 р. кількість членів кредитних спілок становила 479,0 тис. осіб, що на 342,6 тис. осіб (58,3 \%) менше, ніж на кінець 2014 р. Загальний обсяг активів кредитних спілок на 31.12 .2018 р. становить 2218,4 млн грн і він зменшився на 120 млн грн, або на $5,14 \%$ порівняно 3 відповідною датою 2014 p. (2 338,7 млн грн). Загальний обсяг капіталу становить 
977,1 млн грн та порівняно 331.12 .2014 р. зменшився на 72 млн грн, або на 6,83\%.

Окрім цього, простежується тенденція до зменшення кількості кредитних спілок $(39,22 \%)$ та їх членів $(41,70 \%)$. Активи та капітал при цьому залишаються відносно незмінними. Обсяги наданих кредитів, як і отриманих внесків, зростають незначними темпами, в середньому на 5,8 \%, починаючи з 2015 p.

Аналізуючи тенденції, що відбуваються у світі та окремо в Україні, відзначаємо дві кардинально різні ситуації. Тоді як у світі кредитні спілки розвиваються, збільшується їх кількість, кількість їх членів та обсяги активів, в Україні, як згадувалось вище, відбуваються негативні зміни. На нашу думку, роботу кредитних спілок дуже ускладнює стрімке падіння рівня платоспроможності позичальників, що призвело до масових не платежів за кредитами i, як наслідок, погіршення якості кредитних портфелів. 3 огляду на зазначене вище, вважаємо, що з часом роль кредитних спілок на фінансовому ринку України зменшуватиметься.

Досліджуючи питання розвитку кредитних спілок, відзначаємо, що окрім проблем, які притаманні усім небанківським фінансовим установам, можна виокремити таку, як незацікавленість населення у послугах кредитних спілок. Першим фактором, котрий, на наш погляд, зупиняє споживача від користування послугами кредит- них спілок, є потреба ставати іiі членом. А, як показує досвід, більша частина населення не готова брати на себе подібні зобов'язання. Другим фактором $є$ те, що на сьогодні на фінансовому ринку існують альтернативні, більш доступні та легші для розуміння послуги. Отримати кредит можна у банку, чи скористатися послугами фінансових компаній навіть не виходячи 3 дому. Третім фактором, на нашу думку, є відсутність системи гарантування вкладів у кредитних спілках. Ця обставина змушує населення обирати банки, де їх вклади будуть гарантовані державою.

Послуги ломбардів мають високий попит в Україні, що дає змогу їм успішно функціонувати на ринку фінансових послуг. Незважаючи на скорочення кількості ломбардів упродовж останніх п'яти років, що пов'язано 3 посиленням вимог до капіталу, кількість відокремлених підрозділів продовжує зростати. Кількість ломбардів з 2014 по 2018 рр. скоротилася на 24,74 \% (118 ломбардів), а кількість відокремлених підрозділів зросла на $24,77 \%$ (1225 підрозділи) (табл. 2). Власний капітал 92,42 \% ломбардів має тенденцію до росту, в середньому щорічно зростаючи на 18,1 \%. Динаміка активів ломбардів має тенденцію до зростання (за п'ять років приріст становить $117,58 \%$ ), що відповідає загальній тенденції збільшення кількості ломбардів та їх ділової активності.

Табл. 2. Динаміка основних показників діяльності ломбардів, станом на кінець року [7]

\begin{tabular}{|c|c|c|c|c|c|c|}
\hline Показник & 2014 & 2015 & 2016 & 2017 & 2018 & $2019 *$ \\
\hline Кількість ломбардів & 477 & 482 & 456 & 415 & 359 & 343 \\
\hline Кількість відокремлених підрозділів & 4946 & 5672 & 6101 & 6180 & 6171 & 6120 \\
\hline Активи по балансу, млн грн & 1710,3 & 2218,6 & 3317,7 & 3763,7 & 3721,3 & 3924,4 \\
\hline Власний капітал, млн грн & 970,37 & 1100,2 & 1481,6 & 1648,5 & 1867,2 & 1927,1 \\
\hline $\begin{array}{l}\text { Сума наданих фінансових кредитів під заста- } \\
\text { ву за період, млн грн }\end{array}$ & 8410,8 & 12459,7 & 16718,0 & 16389,0 & 16442,3 & 9051,9 \\
\hline $\begin{array}{l}\text { Кількість наданих фінансових кредитів під } \\
\text { заставу, тис. один. }\end{array}$ & 10930,11 & 10600,0 & 11943,6 & 12226,3 & 11749,5 & 5890,5 \\
\hline
\end{tabular}

*Примітка: дані за 6 місяців.

Обсяг наданих фінансових кредитів під заставу за п'ять років зріс більше ніж удвічі, темп приросту сягає 95,5%. До 2017 р. ломбарди впевнено лідирували за обсягами наданого кредитування і показники стрімко зростали: у 2015 р. обсяги наданих фінансових кредитів зросли на 48 \%, а у 2016 р. - ще на 34 \%. Ломбарди залишаються одним із найбільш консервативних і стабільних фінансових інститутів для населення через те, що їх діяльність орієнтована на видачу дрібних та короткотермінових кредитів, предметом застави зазвичай $\epsilon$ найбільш ліквідне майно. Більшість кредитів (76\%) надається під заставу виробів із дорогоцінних металів та каміння, 23,6 \% кредитів надаються під заставу побутової техніки.

Вважаємо, що популярність ломбардів зумовлена посиленням макроекономічної нестабільності та погіршенням добробуту населення. Ломбарди надають кошти швидко, без додаткових документів, а кредитна історія позичальника не впливає на рішення щодо надання позики. Але водночас, кредити, надані ломбардами передбачають значну переплату, можливі штрафи в разі протермінування погашення кредиту, а також продаж предметів застави без попередження.

Основні показники діяльності ломбардів мають позитивну динаміку. Таке зростання зумовлене збільшенням попиту на послуги ломбардів. Негативним $\epsilon$ те, що попит на послуги ломбардів зростає внаслідок погір- шення рівня життя населення. Хоч збільшення активів ломбардів наразі не має вагомого впливу на економічне зростання, ми можемо зробити висновок, що макроекономічна ситуація у країні сприятиме розвитку ломбардів.

Недержавні пенсійні фонди (НПФ), хоч і охоплюють значно меншу частину ринку, проте $\epsilon$ важливою складовою ринку фінансових послуг. Згідно з даними Державного реєстру фінансових установ, станом на 31.12.2018 р., в Україні діяло 62 недержавні пенсійні фонди, що на 18,4 \% менше, ніж у 2014 р. та 22 адміністратори НПФ, що менше на 8,3\% [7]. Ця тенденція є негативною для економіки, оскільки обмежує пропозицію довготермінових фінансових ресурсів. Відповідно до даних, наведених у табл. 3, динаміка кількості укладених пенсійних контрактів за період 2014-2018 рр. має позитивну тенденцію.

Динаміка кількості укладених пенсійних контрактів збільшилась на 24,9 \%, що свідчить про покращення фінансового стану на ринку недержавного пенсійного забезпечення. У першій половині 2019 р. було укладено 72,7 тис. пенсійних контрактів, що на 9 тис. шт. (14\%) більше, ніж за аналогічний період попереднього року. Також варто зазначити, що кількість вкладників НПФ за п'ять років хоч незначно (2,6\%), але зросла. У першій половині 2019 р. учасниками недержавних пенсійних фондів було 860,8 тис. осіб, що на 1,7 \% більше, ніж за аналогічний період 2018 p. 
Табл. 3. Динаміка основних показників діяльності недержавних пенсійних фондів, станом на кінець року [10]

\begin{tabular}{|l|c|c|c|c|c|c|}
\hline \multicolumn{1}{|c|}{ Показник } & 2014 & 2015 & 2016 & 2017 & 2018 & $2019^{*}$ \\
\hline Кількість недержавних пенсійних фондів & 76 & 72 & 64 & 64 & 62 & 63 \\
\hline Кількість адміністраторів недержавних пенсійних фондів & 24 & 23 & 22 & 22 & 22 & 22 \\
\hline Кількість укладених пенсійних контрактів, тис. шт. & 55,10 & 59,70 & 62,60 & 58,70 & 68,80 & 72,70 \\
\hline Загальна кількість учасників НПФ, тис. осіб & 833,70 & 836,70 & 834,00 & 840,80 & 855,30 & 860,80 \\
\hline Загальна вартість активів НПФ, млн грн & 2469,20 & 1980,00 & 2138,70 & 2465,60 & 2745,20 & 2892,90 \\
\hline Пенсійні внески, всього, млн грн & 1808,20 & 1886,80 & 1895,20 & 1897,30 & 2000,50 & 2071,90 \\
\hline $\begin{array}{l}\text { Пенсійні виплати, млн грн } \\
\text { Прибуток від інвестування активів недержавного пенсійного } \\
\text { фонду, млн грн }\end{array}$ & 421,40 & 557,10 & 629,90 & 696,30 & 809,90 & 878,60 \\
\hline
\end{tabular}

*Примітка: дані за 6 місяців.

Обсяги активів недержавних пенсійних фондів зростають повільними темпами. Активи пенсійних фондів зросли на 276 млн грн, або 11,2\% за п'ять років, і на 356 млн грн, або $14 \%$ за період з 30.06 .2018 по 30.06.2019 р. Розмір пенсійних внесків щорічно зростав у середньому на 2,6 \%. Хоча в основному, як і раніше, основними користувачами послуг НПФ були юридичні особи, але частка їх внесків зменшилась від $96 \%$ у 2014 р. до 90,5 \% у 2018 р. Це сталося внаслідок збільшення внесків від фізичних осіб більше ніж у два рази, приріст становив $141 \%$. Пенсійні виплати в середньому збільшувалися на 18 \% щороку й у 2018 р. дорівнювали 809,9 млн грн.

Метою інвестування пенсійних активів $є$ насамперед збереження пенсійних заощаджень громадян. Стратегія інвестування недержавних пенсійних фондів є більш консервативною, ніж в інших фінансових установ. Для НПФ властиво формувати портфель, до якого входять об'єкти інвестування з мінімальним ступенем ризику. Так, станом на 30.06.2019 переважними напрямами інвестування пенсійних активів стали цінні папери, дохід за якими гарантовано Кабінетом Міністрів України (47,3\%) і депозити в банках (36,4 \% інвестованих активів).

Варто зазначити, що недержавні пенсійні фонди, відповідно до даних Нацкомфінпослуг, зосереджені лише в дев'яти регіонах країни, причому понад 70 \% розташовані у Києві. Отже, ми спостерігаємо, що НПФ є найбільш поширеними серед більш розвинених областей, що свідчить про нерівномірний розподіл цих організацій на території України.
За результатами виконаного аналізу відзначаємо, що недержавні пенсійні фонди розвиваються доволі стабільно, але повільно. Вважаємо, що повільний розвиток недержавних пенсійних фондів в Україні зумовлює: відсутність послідовної пенсійної реформи; низька довіра населення до системи пенсійного накопичення; низький інтерес роботодавців до створення та фінансування НПФ; низький рівень доходів населення; низький розвиток фондового ринку, що обмежує можливості НПФ у забезпеченні захисту вкладів від знецінення; відсутність фінансової підтримки з боку держави.

Серед усіх небанківських фінансових установ домінуючі позиції на фінансовому ринку займають фінансові компанії, які акумулюють понад 63 \% усіх активів. За п'ять років кількість фінансових компаній збільшилася на 525 одиниць (126,51\%). Активи зросли майже в 1,5 раза $(144,46 \%)$, а власний капітал більше ніж наполовину $(56,86 \%)$. Така позитивна тенденція є ознакою збільшення кількості пропозиції фінансових послуг на українському ринку (наприклад, лізингових, факторингових операцій тощо), зумовлене зростанням попиту (табл. 4).

Обсяг наданих фінансових послуг збільшився більше ніж удвічі - на 64870 млн грн (119,8 \%). Зрозуміло, важливим показником розвитку фінансового ринку $\epsilon$ розширення спектра послуг, що надають фінансові посередники. На сучасному етапі розвитку економіки фінансові компанії надають позики за рахунок власних коштів, фінансові гарантії, надають послуги лізингу, факторингу, виступають поручителями тощо.

Табл. 4. Динаміка основних показників діяльності фінансових компаній, станом на кінець року [10]

\begin{tabular}{|c|c|c|c|c|c|c|}
\hline Показник & 2014 & 2015 & 2016 & 2017 & 2018 & $2019 *$ \\
\hline Кількість зареєстрованих фінансових компаній & 415 & 711 & 809 & 818 & 940 & 967 \\
\hline Активи фінансових компаній, млн грн & 51264,8 & 95825,0 & 97332,0 & 107533,9 & 125322,3 & 140915,4 \\
\hline Власний капітал, млн грн & 15213,4 & 24939,4 & 22754,5 & 26260,1 & 23863,6 & 25266,9 \\
\hline $\begin{array}{l}\text { Обсяг наданих фінансових послуг фінансовими компа- } \\
\text { ніями, млн грн }\end{array}$ & 54159,0 & 68282,3 & 110420,3 & 228165,0 & 119029,8 & 61586,9 \\
\hline $\begin{array}{l}\text { Залучення фінансових активів із зобов'язанням щодо } \\
\text { наступного їх повернення }\end{array}$ & 644,9 & 1649,3 & 2551,9 & 705,70 & 50,50 & 721,3 \\
\hline Надання гарантій та поручительств & 461,7 & 226,8 & 1961,5 & 5455,0 & 9474,90 & 846,5 \\
\hline $\begin{array}{l}\text { Надання коштів у позику, в т.ч. і на умовах фінансового } \\
\text { кредиту }\end{array}$ & 6984,5 & 7370,7 & 5783,1 & 26940,6 & 47856,90 & 30992,4 \\
\hline $\begin{array}{l}\text { Адміністрування фінансових активів для придбання то- } \\
\text { варів у групах }\end{array}$ & 422,5 & 678,3 & 420,9 & 487,7 & 258,70 & 238,1 \\
\hline Надання послуг з факторингу & 23525,7 & 16555,9 & 16887,5 & 31363,4 & 48105,00 & 23970,3 \\
\hline $\begin{array}{l}\text { Надання послуг з фінансового лізингу (вартість укладе- } \\
\text { них договорів) }\end{array}$ & 257,4 & 20,2 & 67,3 & 153,40 & 673,80 & 369,1 \\
\hline $\begin{array}{l}\text { Управління майном для фінансування об'єктів будівниц- } \\
\text { тва та/або здійснення операцій з нерухомістю (залучені } \\
\text { кошти) }\end{array}$ & 8464,1 & 9737,1 & 12008,0 & 25046,6 & 12610,00 & 4449,2 \\
\hline $\begin{array}{l}\text { Операції з обміну валют та переказу грошових коштів, } \\
\text { млн грн }\end{array}$ & 13398,2 & 32044,0 & 70740,2 & 138012,6 & н/д & н/д \\
\hline
\end{tabular}

*Примітка: дані за 6 місяців. 
Надання гарантій та поручительств користується дедалі більшим попитом з боку користувачів фінансових послуг. Якщо в 2014 р. їх частка серед обсягу усіх наданих послуг становила $0,85 \%$, то у 2018 р. цей показник зріс до 7,96\%. В абсолютному вираженні це означає збільшення обсягу наданих послуг гарантій та поручительств на 9 млрд грн і приріст майже в 20 разів (1952,2\%).

Обсяг наданих коштів у позику збільшився більше ніж удвічі. Частка обсягу наданих коштів у позику у структурі усіх фінансових послуг зросла від 12,9\% у 2014 р. до 40,2 \% у 2018 р. Вартий уваги той факт, що у I півріччі 2019 р. 65 \% договорів 3 надання коштів у позику, зокрема, і на умовах фінансового кредиту, укладалися фінансовими компаніями дистанційно. У такий спосіб було укладено 3,68 млн кредитних договорів на суму 10,5 млрд грн (зростання порівняно з I півріччям 2018 р. у 2,4 раза - на $144,5 \%$ ). Треба зазначити, що 93,0 \% від суми договорів, укладених за I півріччя 2019 р. дистанційно, мають термін дії до 90 днів.

Частка такої послуги, як адміністрування фінансових активів для придбання товарів у групах, серед усіх послуг за п'ять років жодного разу не перевищила 1 \%. У першому півріччі 2019 р. послуги було надано на 68,6 млн грн (40,5 \%) більше, ніж в аналогічному періоді минулого року.

Спостерігаємо зростання ринку факторингу. Так, якщо у 2014 р. послуг з факторингу було надано на суму 23,5 млн грн, то у 2018 р. ця сума становила 48,1 млн грн. Отже, приріст становить 104,5 \%. Попит на послуги з фінансового лізингу також зростає, за п'ять років обсяг наданих послуг збільшився на 161,8 \% й у 2018 р. дорівнював 673,8 млн грн.

Серед усіх небанківських фінансових установ саме фінансові компанії розвиваються найбільш стрімко, збільшуючи активи та обсяги наданих послуг. Можна зробити висновок, що саме вони займуть значну частку у секторі небанківського споживчого кредитування у найближчому майбутньому.

Кількість компаній на страховому ринку України тривалий час демонструє тенденцію до зменшення, за п'ять років стало на 101 страховика $(26,44 \%)$ менше. Загальна кількість функціональних страхових компаній у 2018 р. становила 281, що на 13 установ менше, ніж у попередньому році. А у першій половині 2019 р. їх було 249 , що на 14,4 \% менше, ніж в аналогічному періоді минулого року (табл. 5).

Варто також зазначити, що спостерігається тенденція до скорочення не тільки кількості, але й частки компаній зі страхування життя. Якщо у 2014 р. їх частка становила $14,9 \%$, то у 2018 р. - уже $10,4 \%$.

Незважаючи на скорочення кількості страхових компаній, кількість укладених договорів страхування за п'ять років зросла майже вдвічі. Особливо стрімке зростання спостерігаємо у 2015 р., коли кількість укладених договорів перевищила 200 млн шт. За перше півріччя 2019 р. було укладено 97,6 млн договорів, що на 2,4 \% менше, ніж в аналогічному періоді минулого року.

Табл. 5. Динаміка основних показників діяльності страхових компаній, станом на кінець року [10]

\begin{tabular}{|l|c|c|c|c|c|c|}
\hline \multicolumn{1}{|c|}{ Показник } & 2014 & 2015 & 2016 & 2017 & 2018 & $2019 *$ \\
\hline Кількість зареєстрованих страховиків & 382 & 361 & 310 & 294 & 281 & 249 \\
\hline 3 них: компанії зі страхування життя & 57 & 49 & 39 & 33 & 30 & 26 \\
\hline Кількість укладених договорів страхування, тис. шт. & 134713,2 & 202429,3 & 179471,2 & 185482,9 & 201077,5 & 97623 \\
\hline Активи по балансу, млн грн & 70261,2 & 60729,1 & 56075,6 & 57381 & 63493,3 & 65265,1 \\
\hline $\begin{array}{l}\text { Активи, визначені ст. 31 Закону України "Про стра- } \\
\text { хування", млн грн }\end{array}$ & 40530,1 & 36418,8 & 35071,9 & 36084,6 & 40666,5 & 42729,2 \\
\hline Сформовані страхові резерви, млн грн & 15828,0 & 18376,3 & 20936,7 & 22864,4 & 26975,6 & 29019,70 \\
\hline Чисті страхові премії, млн грн & 18592,8 & 22354,9 & 26463,9 & 28494,4 & 34424,3 & 20120,6 \\
\hline Чисті страхові виплати, млн грн & 4893 & 7602,8 & 8561 & 10256,8 & 12432,6 & 6526,9 \\
\hline
\end{tabular}

*Примітка: дані за 6 місяців.

Активи та розмір страхових резервів $є$ індикаторами фінансової стійкості та спроможності виконувати взяті на себе зобов'язання. У період з 2014 по 2016 р. разом зі зменшенням кількості компаній, скорочувалися і активи, а позитивна тенденція почалася у 2017 р. та триває і до сьогодні. 3 огляду на те, що спочатку активи скоротилися більш ніж на $20 \%$, то вони й досі не досягли рівня 2014 р. Станом на кінець 2018 р. активи страхових компаній по балансу становили 63493,3 млн грн, що на 9,6\% менше, ніж у 2014 р. Так, якщо обсяги активів по балансу скоротилися, то нетто-активів зросли на 0,34 \% (див. табл. 5).

Власні та залучені кошти страхові компанії використовують для придбання фінансових ресурсів з метою отримання додаткових доходів. Варто зазначити, що страхові компанії мають значний потенціал для сприяння сталому розвитку вітчизняного підприємництва шляхом розміщення страхових резервів у реальному сектоpi економіки. Упродовж п'яти останніх років динаміка їх обсягу демонструє щорічне зростання, однак воно, в основному, спричинене девальвацією гривні та переоцінкою залишків валютних активів страхових компаній.
Причини низької популярності страхових компаній 3 довготермінового страхування життя такі самі, як і в недержавних пенсійних фондів: макроекономічна нестабільність, що підриває довіру з боку інвесторів та скорочує реальні доходи населення, а також відсутність системи гарантування вкладів.

Висновки. У 2018-2019 рр. було вжито низку заходів для покращення ситуації на фінансовому ринку. Серед них: посилення вимог до платоспроможності страховиків і кредитних спілок, до власного капіталу ломбардів, запровадження вимог до договорів страхування життя, до кредитних посередників та до їх діяльності у сфері споживчого кредитування на ринку небанківських фінансових послуг, запровадження методики розрахунку загальної вартості кредиту для споживача, запровадження додаткових відрахувань внесків страховиків до централізованих фондів з метою "зв'язування" коштів страховиків у разі їх банкрутства, установлення вимог щодо формування кредитними спілками резервів за операціями із фінансовими активами.

Разом 3 тим, основними проблемами, що перешкоджають розвитку небанківських фінансових установ в Україні, є: 
1. Неефективне державне регулювання діяльності небанківських фінансових установ, зокрема, невідповідність чинного законодавства потребам та стану розвитку фінансового ринку.

2. Низький рівень довіри населення, а також недостатня поінформованість щодо діяльності небанківських фінансових установ.

3. Скорочення реальних доходів населення, що ускладнює накопичення коштів 3 метою інвестування у фінансовий сектор.

Отже, можемо підсумувати, що для покращення діяльності фінансового посередництва в Україні необхідно:

1. Розробити комплексну стратегію з розвитку усіх фінансових посередників, як банківських, так і небанківських.

2. Сформувати сприятливе інформаційне середовище для відновлення довіри до небанківських фінансових посередників.

3. Розробити підходи у державній політиці, спрямовані на стабілізацію макроекономічної ситуації у країні.

\section{References}

1. Pro finansovi posluhy ta derzhavne rehuliuvannia rynkiv finansovykh posluh: Zakon Ukrainy vid 12.1yp.2001 r. № 2664-III. Retrieved from: https://zakon1.rada.gov.ua. (data zvernennia 24.02.2020) . [In Ukrainian].

2. Chunytska, I. I. (2015). Rozvytok finansovoho rynku v Ukraini: hlobalni vyklyky ta perevahy. Ekonomika ta derzhava, 10, 40-44. [In Ukrainian].
3. Didenko, L. V. (2018). Doslidzhennia diialnosti nebankivskykh finansovykh ustanov yak uchasnykiv suchasnoho rynku finansovykh posluh. Ekonomichnyi analiz, 28(4), 88-94. [In Ukrainian].

4. Konina, M. O. (2016). Suchasnyi stan finansovoho rynku Ukrainy ta shliakhy yoho vdoskonalennia. Ekonomichnyi dyskurs, 2, 183192. [In Ukrainian].

5. Ksondz, S. M. (2013). Rol finansovoho poserednytstva na rynku finansovykh posluh Ukrainy. Naukovi zapysky Natsionalnoho universytetu "Ostrozka akademiia". Ser. Ekonomika, 24, 224-229. Retrieved from: https://ecj.oa.edu.ua/articles/2014/n24/44.pdf (data zvernennia 24.02.2020). [In Ukrainian].

6. Lavryk, O. L. (2015). Sutnist finansovoho poserednytstva na suchasnomu etapi rozvytku ekonomiky Ukrainy. Ekonomichnyi analiz, 19(1), 185-192. [In Ukrainian].

7. Ohliad rynkiv finansovykh posluh. Natskomfinposluh. Retrieved from: https://www.nfp.gov.ua/ua/Ohliad-rynkiv.html (data zvernennia 24.02.2020) . [In Ukrainian].

8. Osadchyi, Ye. S. (2017). Rozvytok mizhnarodnoi infrastruktury kredytnoi kooperatsii. Ekonomika ta derzhava, 4, 64-68. [In Ukrainian].

9. Polishchuk, Ye. A. (2014). Evoliutsiia ta peredumovy rozvytku nebankivskykh finansovykh ustanov v Ukraini. Biznes Inform, 9, 260-265. [In Ukrainian].

10. Prokopenko, Zh. V. (2016). Suchasnyi stan rynku nebankivskykh finansovykh ustanov: pensiine zabezpechennia, investytsii ta lizynh. Ekonomika ta derzhava, 8, 85-96. [In Ukrainian].

11. Ruda, O. L. (2019). Suchasnyi stan diialnosti nebankivskykh kredytnykh ustanov v Ukraini. Prychornomorski ekonomichni studii, 2, 84-88. [In Ukrainian].

12. Shkolnyk, I. O. (2018). Periodyzatsiia rozvytku finansovoho sektoru ta finansovoho nahliadu v Ukraini. Finansy Ukrainy, 3, 97115. [In Ukrainian].

N. P. Drebot, Ya. A. Tanhak, M. M. Mykolyshyn

Lviv Educational and Research Institute of Banking University, Lviv, Ukraine

\section{TRENDS IN THE DEVELOPMENT OF NON-BANKING FINANCIAL INSTITUTIONS IN THE FI- NANCIAL SERVICES MARKET OF UKRAINE}

Financial institutions play a decisive role in the overall development of individual sectors of the economy and perform an important socio-economic function by attracting and then redistributing the borrowed funds to other financial assets. The experience of developed countries shows that the effective functioning of non-banking financial institutions has a significant economic effect. This is demonstrated by the ability to effectively influence the growth of investment resources in the country's economy, meeting the needs of economic entities in the required capital. This trend is especially relevant for Ukraine in the current conditions of formation of an investment-innovative model of development of the national economy and its financial systems. The main activities of modern nonbanking financial institutions are related to the accumulation of savings of the population by attracting funds for deposits, issue of own shares, bonds, sale of insurance policies; lending to a certain sphere of economy or economic activity, a population group; providing mortgage loans; organization of pension and social security of the population; transactions within the framework of credit mutual assistance. In this article the current state of non-banking financial intermediation in Ukraine is analyzed. The problems of the domestic non-banking financial sector in the current economic conditions are investigated. The most characteristic signs of systemic problems in the non-banking financial sector of Ukraine in recent years have been identified. The directions of increasing the efficiency of the functioning of joint investment institutes are offered. The modern tendencies of development of the domestic insurance market are investigated. Measures have been formulated to increase the efficiency of the insurance market participants. The main factors that impede the development of non-state pension insurance are identified. Ways to improve the system of non-state pension insurance in Ukraine are suggested. Problems of functioning of domestic credit unions are singled out and directions for further intensification of their activity are worked out. Measures to ensure financial stability and effective development of the non-banking financial sector of Ukraine are proposed.

Keywords: National Financial Services Commission; financial companies; pawnshops; credit unions; pension funds; insurance companies. 